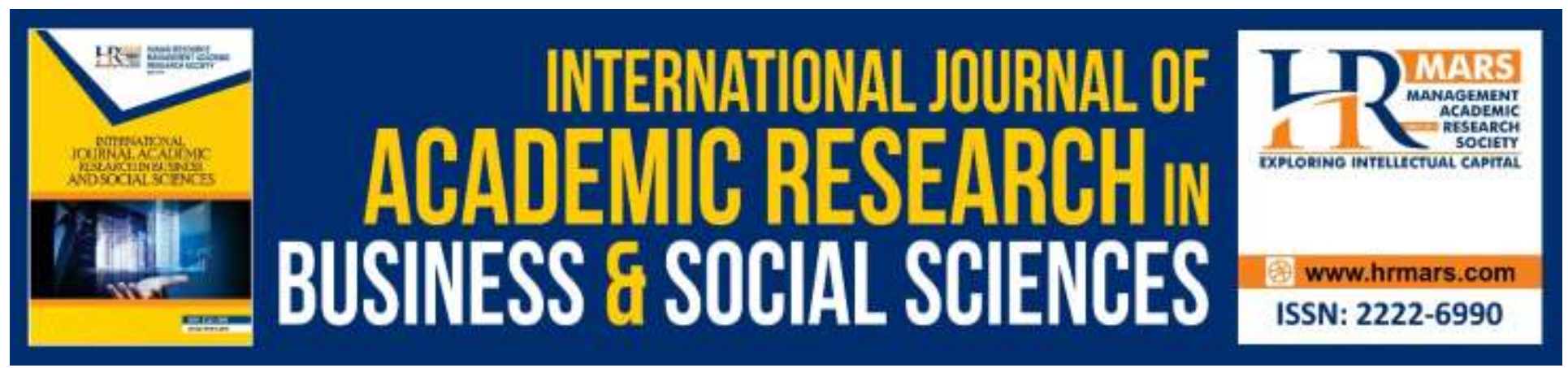

\title{
Construct Validity and Reliability of Social Support Assessment Instrument to Identify Football Talent among Malaysian Male Players Aged 13 to 14 Years
}

Ahmad Hashim, Khairul Sham Hanapiah \& Zulakbal Abd Karim

To Link this Article: http://dx.doi.org/10.6007/IJARBSS/v9-i11/6558 DOI: 10.6007/IJARBSS/v9-i11/6558

Received: 02 September 2019, Revised: 19 September 2019, Accepted: 01 October 2019

Published Online: 25 October 2019

In-Text Citation: (Hashim, Hanapiah, \& Karim, 2019)

To Cite this Article: Hashim, A., Hanapiah, K. S., \& Karim, Z. A. (2019). Construct Validity and Reliability of Social Support Assessment Instrument to Identify Football Talent among Malaysian Male Players Aged 13 to 14 Years. International Journal of Academic Research in Business and Social Sciences, 9(11), 421-430.

Copyright: (C) 2019 The Author(s)

Published by Human Resource Management Academic Research Society (www.hrmars.com) This article is published under the Creative Commons Attribution (CC BY 4.0) license. Anyone may reproduce, distribute, translate and create derivative works of this article (for both commercial and non-commercial purposes), subject to full attribution to the original publication and authors. The full terms of this license may be seen at: $\underline{\text { http://creativecommons.org/licences/by/4.0/legalcode }}$

Vol. 9, No. 11, 2019, Pg. 421 - 430

Full Terms \& Conditions of access and use can be found at http://hrmars.com/index.php/pages/detail/publication-ethics 


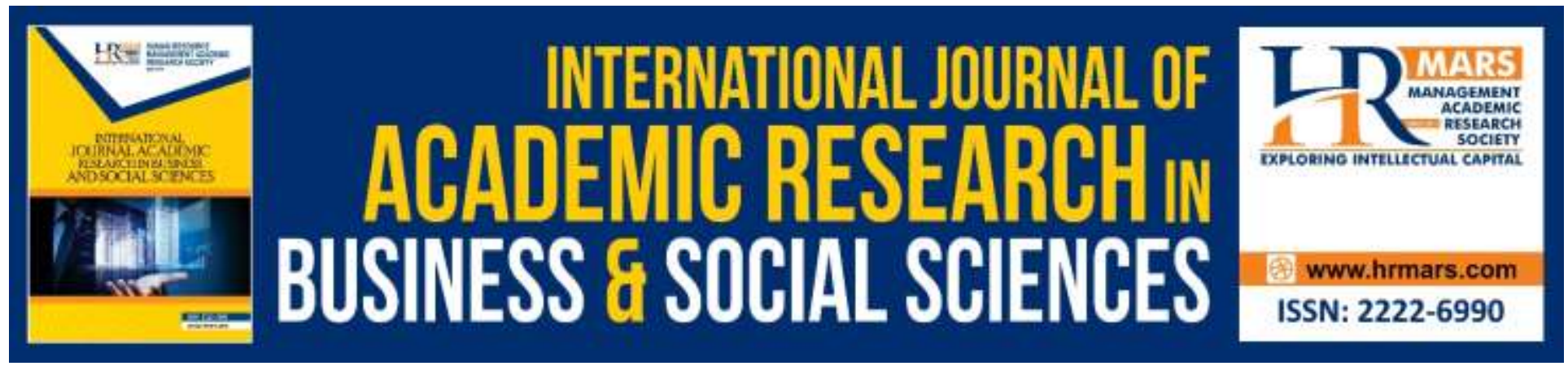

\title{
Construct Validity and Reliability of Social Support Assessment Instrument to Identify Football Talent among Malaysian Male Players Aged 13 to 14 Years
}

\author{
Ahmad Hashim, Khairul Sham Hanapiah \& Zulakbal Abd Karim
} Faculty of Sports Science and Coaching, Sultan Idris Education University, Tanjong Malim, Perak, Malaysia

Email: ahmad@fsskj.upsi.edu.my

\begin{abstract}
The main aim of this study is to obtain the contract validity and reliability of social support assessment instrument to identify football talent among Malaysian male players aged 13 to 14 years. Three sub attributes are used to measure the attributes of social support, which are family, teammates and coaches. A total of 120 male football players aged 13 to 14 years who underwent training under the Malaysia National Football Development Program were selected as study samples. Pearson correlation analysis were used to obtain validity of field experts. Cronbach's alpha analysis were used to obtain reliability coefficient of the assessment instrument on social support. Factor analysis was used to obtain the construct validity of the questionnaire items. Findings of the study show that the construct validity of 35 questionnaire items of overall 60 items $(r=.50)$, field expert validity $(r=.96)$, reliability total value $(\alpha=.92)$ and the internal consistency coefficient for each sub attributes are family $(\alpha=.81)$, teammates $(\alpha=.85)$ and coaches $(\alpha=.83)$. Based on the findings, social support assessment instrument showed highly validity, reliability and acceptable to measure the extent to which a football young player believes that his need for supports, information and feedbacks are fulfilled by the family, teammates and coaches.
\end{abstract}

Keywords: Construct Validity, Reliability, Social Support, Family, Teammates and Coaches.

\section{Introduction}

The importance of social support mechanisms during athletes' developmental years has been highlighted. Social support refers to a social network's provision of psychological and material resources intended to benefit an individual's ability to cope with stress (Cohen, 2004). According to Barrera (1986), social support can be divided into three categories namely social 
embeddedness, perceived support and enacted or received support. Social embeddedness refers to the connections that individuals have to significant others in their social environments, perceived support is the individual's perception that support will be readily available from the members of the social network as needed while enacted or received support is the physical, emotional, material and non-material help from the members of the social network. Among the factors influencing athletes' career development and transitions, researchers have traditionally focused on the micro-environment (for example, family, other athletes/peers and coaches) (Henriksen, Stambulova, \& Roessler, 2010; Larsen, Alfermann, Henriksen, \& Christensen, 2013). Interaction between the family, teammates and coaches give impact and influence on young player's values, beliefs, emotions, attitude and dedication toward football (i.e. decision-making and thought processes in relation to participation, individual goals and performance expectations) (Reilly et al., 2003).

According to Sheridan, Coffee, \& Lavallee (2014), the support gained from interpersonal relationships plays an important role in the development of sports talent. The environment of social support helped the players to focus on holistic lifestyles, handling dual careers (sport and school), developing the ability to work hard, being self-aware and responsible for their own training (Larsen et al., 2013). Previous studies have shown that the roles of parents, teammates and coaches supports have been explored through two contemporary motivational theories which are achievement goal theory (Ames, 1992) and self-determination theory (Deci \& Ryan, 1985). This theoretical approach identifies key dimensions of the sports environment and motivational mechanisms through support given by others that affect how players think, feel and act (Sheridan et al., 2014). Previous studies have discussed the important roles of parents, teammates and coaches in optimizing players' ability to meet challenges during different phases of talent development (Henriksen et al., 2010; Rees \& Hardy, 2000; Reeves, Mcrobert, Littlewood, \& Simon, 2018).

Parents has the most influence in the development of talent in sports from early childhood to late adolescence by providing various support (for example, finance, transportation and emotion) during the sampling, specializing and investment years (Cote, 1999). Coaches play an important role in the year of specialization and investment (Cote, 1999) by providing high quality training programs (Li et al., 2014) and building good relationships with athletes through (a) trust and respect, (b) understand the athletes needs and (c) care for athletes as individuals rather than performers (Guinan et al., 2002). Meanwhile, teammates play an important role in supporting long-term athlete involvement and commitment to the sport (Li et al., 2014). Teammates are not only important for getting information in a competitive sports environment but also for psychological adjustment and moral and social development (Smith, 2003). Evidence from non-elite, junior elite, elite and super-elite athletes proven the influence of social groups, social support and support networks (including family, teammates and coaches) during their career development and transitions (Rees et al., 2016; Reeves, Mcrobert, Littlewood, \& Simon, 2018).

The development of football expertise requires appropriate social support mechanisms. The literature on football expertise highlights the importance of the parents, teammates and coaches supports in developing talented young players at various stages of their careers (Reilly 
et al., 2003; Williams \& Reilly, 2000). At youth level, family and teammates are responsible for the young players with personal development, lifestyle and attitudes, general health and interest in football while coaches must provide their young players with playing opportunities, protection from exploitation and abuses, educational programs, facilities and equipment for training and playing, encouragement and advice, mediation and strong leadership (Asian Football Confederation, 2000). Based on literature review and Asian Football Confederation coaching manual, researchers constructed the questionnaire instrument of social support assessment. The questionnaire instrument refers to the way of players doing self-assessment about their relationships with family, teammates and coaches. Without social supports, young players will be demotivated and this could destroys their self-confidence and enjoyment of the football games.

\section{Objective}

This study aims to obtain the construct validity and reliability of social support assessment instrument to identify football talent among Malaysian male players aged 13 to 14 years.

\section{Methodology}

Methodology of this study focuses on the study design, study population and sample, study variables, research instrumentation and data analysis procedures.

\section{Research Design}

This cross-sectional study is divided into three phases. The first phase started with the construction of social support assessment questionnaire instrument and obtaining validity of the field experts. Second phase is the determination of the reliability of the questionnaire items. The third phase involves the measurement of construct validity of the questionnaire items.

\section{Sample}

The study population are football players aged 13 to 14 years who has been trained under the Malaysia National Football Development Program in 2018/2019. The researchers randomly selected 120 players after taking into consideration of absence or mortality factor (Konting, 2009) and the sample size of minimum 100 participants for factor analysis (Hashim, 2014).

\section{Variables}

In this study, the dependent variable is the football playing ability score, while independent variables are the scores of each sub attributes of family, teammates and coaches. Table 1 shows the study variables.

\section{Instrument}

The researchers developed the questionnaire of assessment instrument on social support by using the 5 points Likert scale ( $1=$ never, $2=$ rarely, $3=$ sometimes, $4=$ often and $5=$ always). At the initial stage of the study, the social support assessment instrument has 60 questionnaire items to measure three sub attributes namely family, teammates and coaches. A total of 120 
INTERNATIONAL JOURNAL OF ACADEMIC RESEARCH IN BUSINESS AND SOCIAL SCIENCES

Vol. 9, No. 11, November, 2019, E-ISSN: 2222-6990 @ 2019 HRMARS

respondents were selected in this study to identify the validity and reliability of questionnaire items.

Table 1. Variables of Study

\begin{tabular}{|c|c|c|}
\hline Attribute & Sub Attribute & Indicator \\
\hline \multirow[t]{2}{*}{ Social Support } & Family and Teammates & $\begin{array}{l}\text { - } \text { Personal development } \\
\text { - Encouragement and advice } \\
\text { - Interest in football } \\
\text { - Financial investment } \\
\text { - Time investment }\end{array}$ \\
\hline & Coaches & $\begin{array}{l}\text { - } \text { Career progression } \\
\text { - Educate and encouragement } \\
\text { - Expectation toward player } \\
\text { - Game and training } \\
\text { - Time Involvement }\end{array}$ \\
\hline
\end{tabular}

\section{Data Analysis Procedures}

Statistical Package for the Social Sciences (SPSS) 21.0 version software was used to analyses the data of assessment instrument on social support. Pearson correlation analysis was used to obtain the validity of field experts based on the consensus of the three expert panels. Cronbach' alpha analysis was used to obtain the questionnaire's reliability and internal consistency coefficient questionnaire items. Factor analysis attempts to identify a small set of factors that represents the underlying relationships among a group of related variables (Pallant, 2010).

\section{Results}

Based on the suggested formula of Noah \& Ahmad (2005) for expert panel evaluation on 10 questionnaire items being valued at scale 1 to 5 to verify the instrument of questionnaire, the value of field experts validity obtained is $r=.96$. A total of 60 questionnaire items have been developed to assess the influence of social support in football based on three sub attributes. The sub attributes are family, teammates and coaches. Based on the factor analysis results, only 35 items were accepted as valid social support questionnaire items. Cronbach's alpha analysis of questionnaire items obtained high reliability total value of $\alpha=.92$ and the internal consistency coefficient for each sub attributes are family $(\alpha=.81)$, teammates $(\alpha=.85)$ and coaches $(\alpha=.83)$. Table 1, 2 and 3 shows the results of factor analysis.

Table 1. Bartlett's dan Kaiser-Meyer-Olkin (KMO) Test Results

Kaiser-Meyer-Olkin Measure of Sampling Adequacy.

Approx. Chi-Square

Bartlett's Test of Sphericity

Df

4202.499

Sig.

Kaiser's criterion technique was used to determine the number of components. Components with only one or more eigenvalue were selected in this analysis. There are 17 
INTERNATIONAL JOURNAL OF ACADEMIC RESEARCH IN BUSINESS AND SOCIAL SCIENCES

Vol. 9, No. 11, November, 2019, E-ISSN: 2222-6990 @ 2019 HRMARS

analysis components with more than one eigenvalue. Finding in Table 1 shows the results of all 60 attribute analysis components on social support explained 72.7 per cent variance. The matrix component shows loading in each line expressed that each questionnaire item's correlation with sub attributes comprising family, teammates and coaches.

Table 2. Total Variance Explained

\begin{tabular}{cccc}
\hline \multirow{2}{*}{ Component } & \multicolumn{3}{c}{ Rotation Sums of Squared Loadings } \\
\cline { 2 - 4 } & Total & \% of Variance & Cumulative \% \\
\hline 1 & 9.303 & 15.505 & 15.505 \\
3 & 7.108 & 11.847 & 27.352 \\
& 6.487 & 10.812 & 38.165 \\
\hline
\end{tabular}

Extraction Method: Principal Component Analysis.

To maintain all the three components for the next analysis, the researchers used the varimax rotation method to minimize the number of questionnaire items which has high correlation on every factor. According to Tabachnick \& Fidell (2007), results based on orthogonal rotation is more easy to be translated and reported. Table 2 shows the result of three components rotation using the varimax rotation method. The result shows the first component explained 15.51 per cent of variance, the second component explained 11.84 per cent of variance and the third component explained 10.81 per cent of variance. Total amount of variance available which could be explained by all three components was 38.17 per cent variance and the figure remained after rotation.

Table 3 shows loading factor more than $r=.50$ for three component of social support questionnaire. The high matric correlation coefficient value of a test on a measured factor indicated close relation with the factor (Tabachnick \& Fidell, 2007). Based on the Principal Component Analysis, only 35 items showed high communality score from overall 60 questionnaire items. Column one represented assessment instrument of sub attributes on family, the second represented teammates and the third represented coaches. According to Pallant (2010), based on this significant results $(r=.50), 35$ items in this analysis are considered valid for attribute assessment instrument on social support in this study.

Table 3. Construct Validity for Rotated Component Matrix Component

\begin{tabular}{|c|c|c|c|}
\hline \multirow[t]{2}{*}{ Item } & \multicolumn{3}{|c|}{ Component } \\
\hline & 1 & 2 & 3 \\
\hline S17 & .822 & & \\
\hline S19 & .813 & & \\
\hline S18 & .759 & & \\
\hline S58 & .717 & & \\
\hline S22 & .678 & & \\
\hline S4 & .664 & & \\
\hline S27 & .664 & & \\
\hline S40 & .642 & & \\
\hline
\end{tabular}


INTERNATIONAL JOURNAL OF ACADEMIC RESEARCH IN BUSINESS AND SOCIAL SCIENCES Vol. 9, No. 11, November, 2019, E-ISSN: 2222-6990 @ 2019 HRMARS

S38

S56

S35

S60

S16

S3

S44

S59

S6

S39

S30

S24

S55

S23

S52

S42

S51

S50

S45

S34

S33

S54

S53

S48

S32

S46

S29

S47

S10

S25

S49

S57

S31

S43

S11

S8

S13

S21

S1

S15

S12

S9
.640

.624

.615

.613

.601

.600

.593

.579
.640

.618

.616

.575

.570

.534

.533

.528

.515

.507

.506 
S2

S41

S20

S5

S7

S36

S14

$\mathrm{S} 28$

S26

Extraction Method: Principal Component Analysis.

Rotation Method: Varimax with Kaiser Normalization.

a. Rotation converged in 7 iterations.

\section{Discussion}

Factor analysis is the most suitable statistical analysis to obtain the construct validity of the social support assessment instrument. According to Pallant (2010), the aim of factor analysis is to reduce a large number of related variables to a more manageable number. Factor analysis was conducted by following three main steps; firstly, assessment of the suitability of the data for factor analysis, secondly, factor extraction and lastly, factor rotation and interpretation (Pallant, 2010). Out of 60 questionnaire items, a total of 35 found has high validity and reliability in measuring the social support among Malaysian male football players aged 13 to 14 years.

\section{Conclusion}

This study has developed social support assessment instrument to identify football talent among Malaysian male young players. The results in this study indicated that three factors (family, teammates and coaches) were valid and reliable for Malaysian male young football players aged 13 to 14 years. For practical implications, the development of instrument in this study may be valuable tools to measure of perceived social support from family, teammates and coaches among Malaysian male young football players. This instrument measures the extent to which a Malaysian male young football players believes that his need for supports, information and feedbacks are fulfilled by the family, teammates and coaches. Each of these relationships may have an impact and influence on a talented youngster's performance during players' developmental years.

This study has only focused on the relationship between young players and their family, teammates and coaches. This limitation demands further investigations as other significant factors may give impact to the young player's sport performances. Future research should also take into consideration the relationship between young football players with peers, friends and school teachers as these may significantly influences their values, beliefs, emotions, attitude and dedication toward football performance. 
INTERNATIONAL JOURNAL OF ACADEMIC RESEARCH IN BUSINESS AND SOCIAL SCIENCES

Vol. 9, No. 11, November, 2019, E-ISSN: 2222-6990 @ 2019 HRMARS

\section{References}

Ames, C. (1992). Achievement goals and adaptive motivational patterns: The role of the environment. In G. C. Roberts (Eds.), Motivation in sport and exercise (pp. 161-176). Champaign, IL: Human Kinetics.

Asian Football Confederation. (2000). " $A$ " certificate coaching manual. Kuala Lumpur: Asian Football Confederation.

Barrera, M. (1986). Distinctions between social support concepts, measures and models. American Journal of Community Psychology, 14(4), 413-446.

Baumgartner, T. A., \& Hensley, L. D. (2013). Conducting \& reading research in kinesiology (5th ed.). New York, NY: McGraw-Hill Companies.

Cohen, S. (2004). Social relationships and health. American Psychologist, 59(8), 676-684.

Cote, J. (1999). The influence of the family in the development of talent in sport. The Sport Psychologist, 13(4), 395-417.

Deci, E. L., \& Ryan, R. M. (1985). Intrinsic motivation and self-determined human behavior. New York, NY: Plenum Press.

Guinan, D., Greenleaf, C., Chung, Y., \& Guinan, D. (2002). A survey of U.S. Atlanta and Nagano olympians: Variables perceived to influence performance. Research Quarterly for Exercise and Sport, 73(2), 175-186.

Hashim, A. (2014). Panduan analisis data secara efisien: Panduan lengkap berajah untuk menganalisis data. Bandar Baru Bangi: Dubook Press Sdn Bhd.

Henriksen, K., Stambulova, N., \& Roessler, K. K. (2010). Holistic approach to athletic talent development environments: A successful sailing milieu. Psychology of Sport and Exercise, 11(3), 212-222.

Konting, M. M. (2009). Kaedah penyelidikan pendidikan. Ampang: Dawama Sdn. Bhd.

Larsen, C. H., Alfermann, D., Henriksen, K., \& Christensen, M. K. (2013). Successful talent development in soccer: The characteristics of the environment. Sport, Exercise and Performance Psychology, 2(3), 190-206.

Li, C., Wang, C. K. J., \& Pyun, D. Y. (2014). Talent development environmental factors in sport: A review and taxonomic classification. Quest, 66(4), 433-447.

Noah, S. M., \& Ahmad, J. (2005). Pembinaan modul: Bagaimana membina modul latihan dan modul akademik. Serdang: Penerbit Universiti Putra Malaysia.

Pallant, J. (2010). SPSS survival manual: A step by step guide to data analysis using SPSS (4th ed.). New York, NY: McGraw-Hill Companies.

Rees, T., \& Hardy, L. (2000). An investigation of the social support experiences of high-level sports performers. The Sport Psychologist, 14(4), 327-347.

Rees, T., Hardy, L., Gullich, A., Abernethy, B., Cote, J., Woodman, T., Montgomery, H., Laing, S., \& Warr, C. (2016). The Great British medalists project: A review of current knowledge on the development of the world's best sporting talent. Sports Medicine, 46(8), 1041-1058.

Reeves, M. J., Mcrobert, A. P., Littlewood, M. A., \& Simon, J. (2018). A scoping review of the potential sociological predictors of talent in junior-elite football: $2000-2016$. Soccer \& Society, 19(8), 1085-1105.

Reilly, T., Williams, A. M., \& Richardson, D. (2003). Identifying talented players. In T. Reilly \& A. 
M. Williams (Eds.), Science and Soccer (2nd ed., pp. 307-326). London: Routledge.

Sarmento, H., Anguera, M. T., Pereira, A., \& Araujo, D. (2018). Talent identification and development in male football: A systematic review. Sports Medicine, 48(4), 907-931.

Sheridan, D., Coffee, P., \& Lavallee, D. (2014). A systematic review of social support in youth sport. International Review of Sport and Exercise Psychology, 7(1), 198-228.

Smith, A. L. (2003). Peer relationships in physical activity contexts: A road less traveled in youth sport and exercise psychology research. Psychology of Sport and Exercise, 4(1), 25-39.

Tabachnick, B. G., \& Fidell, L. S. (2007). Using multivariate statistics (5th ed.). Boston, MA: Pearson Educational.

Williams, A. M., \& Reilly, T. (2000). Talent identification and development in soccer. Journal of Sports Sciences, 18(9), 657-667. 